\title{
Monitoring and Risk Assessment of Lead and Cadmium in Milks from East of Iran Using Monte Carlo Simulation Method
}

Masoumeh Madani-Tonekaboni ${ }^{1}$, Neda Sadat Aghayan ${ }^{2}$, Roshanak Rafiei Nazari ${ }^{3}$, Solmaz Mirzamohammadi ${ }^{1,4}$ Anna Abdolshahi ${ }^{5}$, Negar Abbasi-Bastami ${ }^{6}$, Majid Arabameri*1

1- Vice-Chancellery of Food and Drug, Shahroud University of Medical Sciences, Shahroud, Iran

2- Department of Food Science, Shahroud Branch, Islamic Azad University, Shahroud, Iran

3- Department of Physics, South Tehran Branch, Islamic Azad University, Tehran, Iran

4- School of Medicine, Shahroud University of Medical Sciences, Shahroud, Iran

5- Food Safety Research Center (Salt), Semnan University of Medical Sciences, Semnan, Iran

6- Department of Pharmacology and Toxicology, Faculty of Pharmacy in Hradec Králové, Charles University, Czech Republic

\section{A B S T R A C T}

Background and Objectives: Milk is an important component of the human diet. Exposure to heavy metals through dairy consumption of contaminated foods endangers human health. The aim of this study was to assess concentrations of lead and cadmium in raw milk samples from east of Iran and their safety risks.

Materials and Methods: In this study, 54 raw milk samples from five regions were selected by cluster sampling and 20 samples of various popular brands of pasteurized milks were randomly purchased from supermarkets in east of Iran. Samples were digested in laboratory using acid digestion method. Concentrations of elements were calculated using graphite furnace atomic absorption spectroscopy. Monte Carlo simulation (MCS) approach was used to assess safety risks and investigate noncarcinogenic effects of lead and cadmium.

Results: The mean concentrations of lead and cadmium in raw milks included 38.15 and $4.67 \pm 0.001 \mu \mathrm{g} / \mathrm{kg}$, respectively. The mean concentrations of lead and cadmium in pasteurized milk included $48.49 \pm 0.001 \mathrm{and} 6.84 \pm 0.001 \mu \mathrm{g} / \mathrm{kg}$, respectively. Moreover, the target hazard quotient (THQ) for adults and children in all groups were reported within the safe limits. There were hence no possible risks of exposure to lead and cadmium as results of raw and pasteurized milk consumptions.

Conclusions: Lead and cadmium levels did not exceed maximum levels (MLs) in any samples of raw and pasteurized milks. Persistent monitoring is a critical action to protect consumers from contaminated foods. The health risk assessment pursuant to Monte Carlo simulation approach demonstrated that children and adults were not at impressive health risk (THQ $<1)$.

Keywords: Lead, Cadmium, Heavy metals, Raw milk, Pasteurized milk, East of Iran

\section{Introduction}

Milk is a high-value nutrient in human diets, reach in macronutrients and micronutrients. Milk, as a perfect food for humans, contains maximum levels of calcium, protein, magnesium and potassium. This explains why it is important to monitor milk for chemical contaminants. Heavy metal contamination frequently occurs in milk and its products $(1,2)$. Although development of technology has led to a higher quality of life, this has also resulted in increased contaminants and environmental problems (3). Some of these contaminants and toxic compounds such as dioxins, pesticides, heavy metals and metalloids enter human food chains directly and indirectly (4). The entrance and accumulation of heavy metals are mainly due to industrial activities, fertilizers, animal manures, municipal sewages, composts and pesticides and soil characteristics of agricultural fields (5). The most fundamental issue of heavy metals is that they are not 
metabolized in the body. After entering the body, heavy metals are not removed but are accumulated in tissues such as fats, muscles, bones and joints. This results in diseases and complications in the body. Of the contaminants entering the human food chain, lead and cadmium are accumulated in the body organs, especially lungs, liver, kidneys, thyroid gland and brain $(6,7)$. Poisoning by lead salts mainly occurs through environment and food intake. Due to solubility in lipids, these compounds are well absorbed through the skin and respiratory tract. The first symptoms of poisoning include tiredness, impaired sleeping and constipation. If the contact time increases, other side effects appear, including colic and anemia. The acute and rare side effect caused by oral absorption in children is encephalopathy (8-10). Cadmium is of metals that are widely dispersed in environment. The major sources of cadmium include industrial compounds and phosphate fertilizers. Cadmium poisoning symptoms include shortness of breath and renal complications. Dairy products, especially milks, are important components of a healthy diet. Studies have proven that consumption of foods containing heavy metals could endanger consumer health $(2,5$, 11-14). Important sources of environmental contamination with cadmium include phosphate fertilizers, water, feed sources, industrial lime, weaving, ceramics and food factories (7). A comparison between these data and those reported in literatures is shown in Table 1.

In general, one of the most important health problems within the present society is food contamination with heavy metals. Of various foods, milk is further studied by researchers because of its wide consumption in all life ages, especially childhood $(25,26)$. Therefore, concentrations of lead and cadmium in raw milks produced in various regions of Shahroud, east of Iran, were assessed and compared to international standards. Then, the health risk of these metals in milk was assessed.

\section{Materials and Methods}

Reagents: Deionized water (DI) (resistance over 18 $\mathrm{M} \Omega / \mathrm{cm}$; Millipore, Bedford, MA, USA) was used for the preparation of solutions and standards. The nitric acid (67\%), hydrochloric acid (32\%) and hydrogen peroxide (30\%) were purchased from Fisher Scientific (Fair Lawn, NJ, USA). To verify the accuracy of the lead and cadmium analyzes, certified reference materials of (CRM) BCR-063 and BCR-150 skim milk powders were used.

Materials: In total, 54 raw milk samples from five regions of Eastrn Iran were collected using cluster sampling and 20 samples of various popular brands of pasteurized milks were randomly purchased from supermarkets in east of Iran, 2015. Milk production in east of Iran included nearly 17,800 tons in 2015 (31).

Table 1. The mean lead and cadmium concentrations in milk samples from various countries

\begin{tabular}{|c|c|c|c|c|c|c|}
\hline country & lead & $\mathrm{N}$ & cadmium & $\mathrm{N}$ & Origin/unit & Reference \\
\hline Iran & $0.018 \pm 0.001$ & 100 & $0.003 \pm 0.001$ & 100 & Buffalo (mg kg-1) & $(15)$ \\
\hline Iran & $0.010 \pm 0.001$ & 100 & $0.002 \pm 0.001$ & 100 & Ewe (mg kg-1) & (15) \\
\hline Italy & $0.18 \pm 0.069$ & 8 & $0.07 \pm 0.019$ & 8 & Ewe (mg kg-1) & (16) \\
\hline China & $35.01 \pm 8.63$ & 8 & $4.53 \pm 3.01$ & 8 & Cow $(\mu \mathrm{g} \mathrm{kg}-1)$ & (17) \\
\hline Turkey & $3.17 \pm 0.86$ & 4 & $0.13 \pm 0.11$ & 4 & Ewe (mg kg-1) & (18) \\
\hline Italy & $0.06 \pm 0.02$ & 10 & $<0.03$ & 37 & Ewe (mg kg-1) & (19) \\
\hline Turkey & $3.01 \pm 0.89$ & 4 & $0.11 \pm 0.07$ & 4 & Goat (mg kg-1) & (18) \\
\hline Italy & $0.06 \pm 0.02$ & 10 & $<0.03$ & 37 & Goat (mg kg-1) & (19) \\
\hline Japan & $12.95 \pm 2.94$ & 8 & $2.01 \pm 1.06$ & 8 & Cow $(\mu \mathrm{g} \mathrm{kg}-1)$ & (17) \\
\hline Nigeria & 5.50176 & 17 & 1.63176 & 17 & Cow $(\mu \mathrm{g} \mathrm{kg}-1)$ & (20) \\
\hline India & $0.060 \pm 0.008$ & 216 & - & - & Buffalo (mg l-1) & (21) \\
\hline California & $92.1 \pm 2.9$ & 111 & $97.5 \pm 2.5$ & 111 & Cow $(\mu \mathrm{g} \mathrm{kg}-1)$ & (22) \\
\hline Croatia & $0.035 \pm 0005$ & 10 & $0.011 \pm 0.003$ & 10 & Ewe (mg kg-1 & (23) \\
\hline Croatia & $0.027 \pm 0.06$ & 60 & 0.037 & 60 & Cow (mg kg-1) & (24) \\
\hline Egypt & $0.327 \pm 0.124$ & 21 & $0.007 \pm 0.004$ & 21 & Cow (mg kg-1) & (7) \\
\hline
\end{tabular}


Sample preparation: Each sample included $100 \mathrm{~g}$ of milk collected under sterile conditions. Samples were transferred to the laboratory using flasks containing ice. The screw-cap test tubes were used to prepare and transfer samples. To ensure that the tubes are free of lead, all tubes were washed with acid before sampling. First, tubes were soaked in $10 \%$ of hydrochloric acid for $24 \mathrm{~h}$ according to the Iranian National Standard (INS) No. 419. Then, tubes were rinsed with water and soaked in distilled water for $24 \mathrm{~h}$. Finally, the tubes were rinsed with distilled water (DW) and dried. After drying, the tube caps were closed and used for the sampling.

Lead and cadmium assessments: Lead and cadmium were assessed using graphite furnace atomic absorption spectroscopy with longitudinal AC Zeeman (Perkin Elmer AAnalyst 600, USA), equipped with a transversely heated graphite atomizer. Preparation of samples for GFAAS was based on a method by Munoz et al. (27). Briefly, the milk sample was mixed with 2 $\mathrm{ml}$ of $65 \% \mathrm{HNO} 3$ and $1 \mathrm{ml}$ of $35 \% \mathrm{H}_{2} \mathrm{O}_{2}$. After digesting and cooling, the solution was diluted with water to a final volume of $25 \mathrm{ml}$. Milk injected into the graphite furnace and atomized at $1600{ }^{\circ} \mathrm{C}$ for lead and $1,400{ }^{\circ} \mathrm{C}$ for cadmium. Triplicate analyses were carried out for each sample. Absorption of standards was record under the same conditions. An average of five consecutive absorptions and the standard curve were used to assess cadmium levels in samples. The limit of detection (LOD), limit of quantitation (LOQ) values included 0.001 and 0.002 for lead and 0.0001 and $0.0002 \mathrm{mg} / \mathrm{kg}$ for cadmium, respectively. Validation reports are presented in Tables 2 and 3. The repeatability of the measurements was reported excellent. Comparison of measured values and certified reference material values are shown in Table 3. ANOVA test was used for the statistical analysis.

Table 2. Validation parameters obtained for lead and cadmium by using GF AAS

\begin{tabular}{lcc}
\hline Parameters & $\mathrm{Cd}$ & $\mathrm{Pb}$ \\
\hline Limit of detection (LOD), $\mathrm{mg} / \mathrm{kg}$ & 0.0001 & 0.001 \\
Limit of quantitation (LOQ), $\mathrm{mg} / \mathrm{kg}$ & 0.0002 & 0.002 \\
\hline Cd, cadmium; $\mathrm{Pb}$, lead & &
\end{tabular}

Health risk estimation: Of distinctive strategies for approaching the risk assessment, Monte Carlo simulation (MCS) is the most practical strategy (Kentel and Aral, 2004). Model significant improvement in risk assessment is guaranteed using Monte Carlo uncertainty simulation (Qu et al., 2015). Crystal Ball Software v.7.2 (Oracle, Decisioneering, Denver, CO, USA) was used for the development of exposure and risk assessment models. Exposure assessment is important in epidemiology studies on risk assessments. In the current study, estimated daily intake (EDI) was used to characterize dietary exposure to heavy metals (lead and cadmium). The following Equation 1 was used to calculate EDI (27):

$$
\mathrm{EDI}=\frac{\mathrm{C}_{\mathrm{metal}} \times \mathrm{E}_{\mathrm{F}} \mathrm{eE}_{\mathrm{D}} \times \mathrm{F}_{\mathrm{IR}}}{\mathrm{W}_{\mathrm{AB}} \mathrm{BT}_{\mathrm{A}}}(1)
$$

Where, $\mathrm{C}_{\text {metal }}(\mathrm{mg} / \mathrm{kg})$ was the concentration of heavy metals in milk; $\mathrm{E}_{\mathrm{F}}$ (365 days/year) was the exposure frequency; $E_{D}$ (30 years for non-carcinogens (27) was the exposure duration; $F_{\text {IR }}(239 \mathrm{ml} /$ person/day for children and $175 \mathrm{ml} /$ person/day for adults) was the average daily milk consumption; $\mathrm{W}_{\mathrm{AB}}(\mathrm{kg})$ was the average body weight ( $15 \mathrm{~kg}$ for children and $70 \mathrm{~kg}$ for adults); and $\mathrm{T}_{\mathrm{A}}$ was the average exposure time calculated by multiplying $\mathrm{E}_{\mathrm{D}}$ to $\mathrm{E}_{\mathrm{F}}(28-31)$.

Non-carcinogenic risk: In this study, a quantitative risk assessment technique was used for noncarcinogenic human health risk assessment using the following THQ Index Equation 2 (32):

$$
\mathrm{THQ}=\frac{\mathrm{EDI}}{\mathrm{R}}_{\mathrm{fD}}(2)
$$

Where, THQ Index was the target hazard quotient index; EDI was the EDI (mg/kg/day); and $\mathrm{R}_{\mathrm{fD}}$ was the oral reference dose $(\mathrm{mg} / \mathrm{kg} /$ day $)$. When THQ was lower than or equal to 1 , no considerable risks were reported $(32,33)$. The $\operatorname{RfD}$ for lead and cadmium included 0.0035 and $0.001 \mathrm{mg} / \mathrm{kg} /$ day, respectively.

Statistical analysis: Data were analyzed using statistical analysis of variance (ANOVA) followed by Tukey multiple comparison test with a significance level of 5\%. Data were analyzed using SPSS Software v.18.0 (SPSS, Inc., Chicago, IL, USA).

\section{Results}

Based on the results, Regions 4 and 2 showed a maximum of $67.84 \mu \mathrm{g} / \mathrm{kg}$ and a minimum of 15.77 $\mu \mathrm{g} / \mathrm{kg}$ of lead concentrations in raw milk samples, respectively (Tables 3, 4, 5 and 6). The mean concentrations of lead and cadmium in samples included 38.15 and $4.67 \mu \mathrm{g} / \mathrm{kg}$, respectively. Statistical analysis of the results showed a significant difference between lead and cadmium levels in raw milks produced in various regions of Eastern Iran. Furthermore, a significant difference was found between the cadmium levels in raw milks produced in 
various regions of Eastern Iran. The average concentrations of lead and cadmium in raw milk samples included 38.15 and $4.67 \mu \mathrm{g} / \mathrm{kg}$, respectively, which differ with concentrations of these heavy metals in other countries. Concentrations of lead and cadmium showed significant differences between the pasteurized milk samples $(\mathrm{P}<0.05)$. In all pasteurized milk samples, the level of cadmium was reported beyond the safe maximum permissible limit (MPl). The average concentrations of lead and cadmium in pasteurized milk were $6.48 \mu \mathrm{g} / \mathrm{kg}$ and $48.49 \mu \mathrm{g} / \mathrm{kg}$, respectively (Tables 3, 4, 5 and 6). Milk brands D and A showed a maximum of $133.1 \mu \mathrm{g} / \mathrm{kg}$ and a minimum of $7.8 \mu \mathrm{g} / \mathrm{kg}$ of the mean lead concentrations, respectively. Milk Brands D and E showed a maximum of $12.5 \mu \mathrm{g} / \mathrm{kg}$ and a minimum of $1.2 \mu \mathrm{g} / \mathrm{kg}$ of the mean cadmium concentrations, respectively (Table 3-5). The EDI $(\mu \mathrm{g})$ of cadmium through milk consumption included $1.58-3.49 \mu \mathrm{g} / \mathrm{kg} \mathrm{BW} /$ day.

Table 3. Descriptive statistics levels of lead in raw milk samples $(\mu \mathrm{g} / \mathrm{kg})$

\begin{tabular}{|c|c|c|c|c|c|c|}
\hline & & region 1 & region 2 & region 3 & region 4 & region 5 \\
\hline sample number & & 10 & 18 & 19 & 11 & 11 \\
\hline Standard Deviation & & 21.361 & 14.59 & 18.09 & 39.53 & 17.55 \\
\hline Mean & & 38.08 & 15.77 & 35.23 & 67.84 & 33.84 \\
\hline Maximum & & 83.5 & 44.9 & 60 & 133.1 & 54.2 \\
\hline Minimum & & 7.8 & 0.7 & 1.8 & 24.2 & 6.6 \\
\hline P-value & & & & $\mathrm{p} \leq 0.001$ & & \\
\hline \multirow[t]{3}{*}{$\mathrm{MRL}^{*}(\mu \mathrm{g} /$ day $)$} & Adults & 75 & 75 & 75 & 75 & 75 \\
\hline & pregnant women, & 25 & 25 & 25 & 25 & 25 \\
\hline & children & 6 & 6 & 6 & 6 & 6 \\
\hline
\end{tabular}

Table 4. Descriptive statistics levels of lead in pasteurized milk samples $(\mu \mathrm{g} / \mathrm{kg})$

\begin{tabular}{|c|c|c|c|c|c|c|}
\hline \multicolumn{2}{|l|}{+2} & Brand A & Brand B & Brand C & Brand D & Brand E \\
\hline \multicolumn{2}{|l|}{ sample number } & 5 & 5 & 5 & 5 & 5 \\
\hline \multicolumn{2}{|c|}{ Standard Deviation } & 25.330 & 33.575 & 17.86 & 45.66 & 12.704 \\
\hline \multicolumn{2}{|c|}{ Mean } & 41.46 & 51.88 & 42.24 & 70.38 & 41.74 \\
\hline \multicolumn{2}{|l|}{ Maximum } & 83.5 & 91.5 & 60 & 133.1 & 54.2 \\
\hline \multicolumn{2}{|l|}{ Minimum } & 15.3 & 15 & 14.3 & 24.2 & 23.1 \\
\hline \multicolumn{2}{|l|}{ P-value } & $\mathrm{p} \leq 0.001$ & & & & \\
\hline \multirow[t]{3}{*}{ MRL* ( $\mu \mathrm{g} /$ day $)$} & Adults & 75 & 75 & 75 & 75 & 75 \\
\hline & pregnant women, & 25 & 25 & 25 & 25 & 25 \\
\hline & children & 6 & 6 & 6 & 6 & 6 \\
\hline
\end{tabular}

Table 5. Descriptive statistics levels of cadmium in raw milk samples $(\mu \mathrm{g} / \mathrm{kg})$

\begin{tabular}{lccccc}
\hline & region 1 & region 2 & region 3 & region 4 & region 5 \\
\hline sample number & 10 & 18 & 19 & 11 & 11 \\
Standard Deviation & 1.741 & 3.99 & 4.21 & 3.65 & 4.72 \\
Mean & 3.16 & 9.17 & 6.44 & 6.97 & 5.07 \\
Maximum & 5.6 & 15.8 & 15.8 & 12.5 & 11.6 \\
Minimum & 0.5 & 4.8 & 0.4 & 1.5 & 0.5 \\
P-value & & & $\mathrm{p} \leq 0.001$ & & \\
average daily intake $(\mu \mathrm{g})$ & 0.44 & 1.28 & 0.9 & 0.97 & 0.70 \\
MRL $(\mu \mathrm{g} /$ day) & 14 & 14 & 14 & 14 & 14 \\
\hline
\end{tabular}


Masoumeh Madani-Tonekaboni, et al: Risk assessment of Cadmium and lead of milk in East Iran

Table 6. Descriptive statistics levels of cadmium in pasteurized milk samples $(\mu \mathrm{g} / \mathrm{kg})$

\begin{tabular}{|c|c|c|c|c|c|c|}
\hline \multirow{2}{*}{\multicolumn{2}{|c|}{ sample number }} & Brand A & Brand B & Brand C & Brand D & Brand $\mathrm{E}$ \\
\hline & & 5 & 5 & 5 & 5 & 5 \\
\hline \multicolumn{2}{|c|}{ Standard Deviation } & 1.72 & 1.954 & 3.75 & 4.04 & 5.2 \\
\hline \multicolumn{2}{|c|}{ Mean } & 3.92 & 7.5 & 7.46 & 7.88 & 5.78 \\
\hline \multicolumn{2}{|l|}{ Maximum } & 6.1 & 9.9 & 10.9 & 12.5 & 11.6 \\
\hline \multicolumn{2}{|l|}{ Minimum } & 1.8 & 5.3 & 1.2 & 1.5 & 1.2 \\
\hline \multicolumn{2}{|l|}{ P-value } & $\mathrm{p} \leq 0.001$ & & & & \\
\hline \multirow[t]{3}{*}{$\operatorname{MRL}^{*}(\mu \mathrm{g} /$ day $)$} & Adults & 75 & 75 & 75 & 75 & 75 \\
\hline & $\begin{array}{l}\text { pregnant } \\
\text { women, }\end{array}$ & 25 & 25 & 25 & 25 & 25 \\
\hline & children & 6 & 6 & 6 & 6 & 6 \\
\hline
\end{tabular}

Monte Carlo simulation is an effective technique to calculate uncertainties of each factor. In this approach, each estimation of parameter distribution is incorporated in the risk assessment equation of results, which covers uncertainty of the input factors (34). In order to assess non-carcinogenic risks of the highlighted elements, THQ was estimated for children and adults. Results demonstrated that values of THQ assessed for lead and cadmium through consumption of raw cow milk included 0.86 and 0.366 for children and 0.0116 and 0.0049 for adults, respectively. The THQ for lead and cadmium through consumption of pasteurized cow milk included 0.910 and 0.54 for children and 0.0146 and 0.0072 for adults, respectively.

\section{Discussion}

In recent years, lead and cadmium in milk and dairy products have appealed much public attentions because of legal food safety issues and consumer concerns. The aims of the current study included assessment of lead and cadmium levels in milk samples based on individual milk consumption frequency of people in Shahroud, east of Iran. Results showed that lead and cadmium levels in the study area were lower than the national levels (Table 4) (35). Bilandz et al. assessed levels of metals in raw milks produced in northern and southern regions of Croatia. The average concentrations of lead in the northern and southern regions included 58.7 and $36.2 \mu \mathrm{g} / \mathrm{ml}$, respectively. The average concentrations of cadmium in northern and southern regions of Croatia respectively included 1.76 and $3.4 \mu \mathrm{g} / \mathrm{ml}$, which were higher than those from the current study (14). In another study, Patra et al. investigated heavy metals in milks of dairy cows near the industrial zones (13). The highest level of cadmium in milk samples included $0.23 \mu \mathrm{g} / \mathrm{ml}$. Tajkarimi et al assessed lead residues in in 97 milks produced in various areas of Iran. The average lead concentration included $7.9 \mathrm{ng} / \mathrm{ml}$ with a range of 1 to $46 \mathrm{ng} / \mathrm{ml}$ (4). Rahimi et al. investigated concentrations of lead and cadmium in 137 milk samples from goat, cow, sheep and buffalo from various regions of Iran using graphite furnace atomic absorption spectrometry. The average lead and cadmium respectively included 1.93 ( 0.18 6.11) and $9.51 \quad(1.84-30.50) \quad \mathrm{ng} / \mathrm{ml}$. Lead concentrations in $8.1 \%$ of the sheep milk samples and $1.9 \%$ of cow milk samples near the industrial cities were higher than Codex Standards (36). Maas et al. assessed levels of trace metals in milk and cheese samples. Concentrations of lead and cadmium were reported as $0.009-0.126 \mu \mathrm{g} / \mathrm{g}$ and $0.34-1.01 \mathrm{ng} / \mathrm{g}$, respectively. They found that metal contents significantly increased when milks turned into cheeses. Relatively, concentrations of lead and cadmium in cheese samples included $0.68-11.37 \mu \mathrm{g} / \mathrm{g}$ and 0.020 $0.925 \mathrm{ng} / \mathrm{g}$, respectively (2). Kim studied lead contents in milks and dairy products in Korea. He found that lead concentrations in raw cow milks from nine districts and in imported butter, cheese, cream and milk from 15 countries were lower than allowable limits (37). Similarly, Najarnezhad reported that milk cadmium contents from West Azerbaijan Province, Iran, included $0.003 \pm 0.001 \mathrm{mg} / \mathrm{kg}$ for buffalo milks; $0.001 \pm 0.001 \mathrm{mg} / \mathrm{kg}$ for raw cow milks; and 0.002 $\pm 0.001 \mathrm{mg} / \mathrm{kg}$ for raw ewe milks (15). A comparison of data reviewed from literatures is presented in Table 6.

The provisional tolerable weekly intakes (PTWI) of $25 \mu \mathrm{g} / \mathrm{kg} \mathrm{BW}$ (equivalent to $3.6 \mu \mathrm{g} / \mathrm{kg} \mathrm{BW} /$ day) of lead are established by the Joint FAO/WHO Expert Committee on Food Additives (JECFA) for all human groups, based on the fact that lead is a cumulative poison. The provisional tolerable monthly intakes (PTMI) of cadmium is reported as $7 \mu \mathrm{g} / \mathrm{kg} \mathrm{BW}$ (or 0.83 
$\mu \mathrm{g} / \mathrm{kg} \mathrm{BW} /$ day) (38). Analysis of samples showed that concentrations of lead and cadmium in all milks from east of Iran were lower than tolerable weekly intake (TWI) levels of these heavy metals. Results of another study in Croatia showed that the TWI of lead in cow and goat milks included approximately 1.37 and $1.84 \%$, respectively $(14,39)$. These results showed that lead concentration in the milk samples included no risks to consumer health including adults, children and pregnant women. A similar report showed the presence of less than permitted levels of lead and cadmium in dairy products in Korea (37). The PTWI of cadmium for adults include $7 \mu \mathrm{g} / \mathrm{kg} \mathrm{BW}$. This equals $47.52 \mu \mathrm{g}$ for lead and $6.70 \mu \mathrm{g}$ for cadmium for individuals with an average weight of $70 \mathrm{~kg}$. Therefore, cadmium in the milk samples included no health risks to consumers. in the present study, the THQ distribution was calculated using the Monte Carlo approach (Fig. 1). Nearly 95\% of iterations for lead and cadmium were below hazard quotient thresholds (1). The estimated mean and median values of THQ for the lead and cadmium were below 1 . Therefore, levels of human exposure to these elements could not cause any deleterious effects and it could be suggested that consumption of milk samples from east of Iran is relatively safe. Sobhanardakan et $a l$. demonstrated that the average health risk index (HRI) through consumption of raw cow milk was estimated as 2.15E-03 and 6.81E-04 for children and adults, respectively. The average HRI through consumption of pasteurized cow milk was estimated as $2.65 \mathrm{E}-03$ and $5.68 \mathrm{E}-04$ for children and adults, respectively. They reported mean HRI values of lower than 1 for the analyzed $\mathrm{Cd}, \mathrm{Cu}, \mathrm{Pb}$ and $\mathrm{Zn}$ in children and adults through consumption of raw and pasteurized cow milks. (40). Meshref et al. found that the THQ values of metals $(\mathrm{Pb}, \mathrm{Cd}, \mathrm{Fe}, \mathrm{Cu}$ and $\mathrm{Zn})$ in Egyptian population through consumption of milks included $2 \mathrm{E}-01,1.7 \mathrm{E}-01,7 \mathrm{E}-02,8 \mathrm{E}-03$ and $1 \mathrm{E}-01 \mathrm{mg} / \mathrm{kg}$ BW/day, respectively. Results showed consumption of milk in this area was nearly free of risks (41).

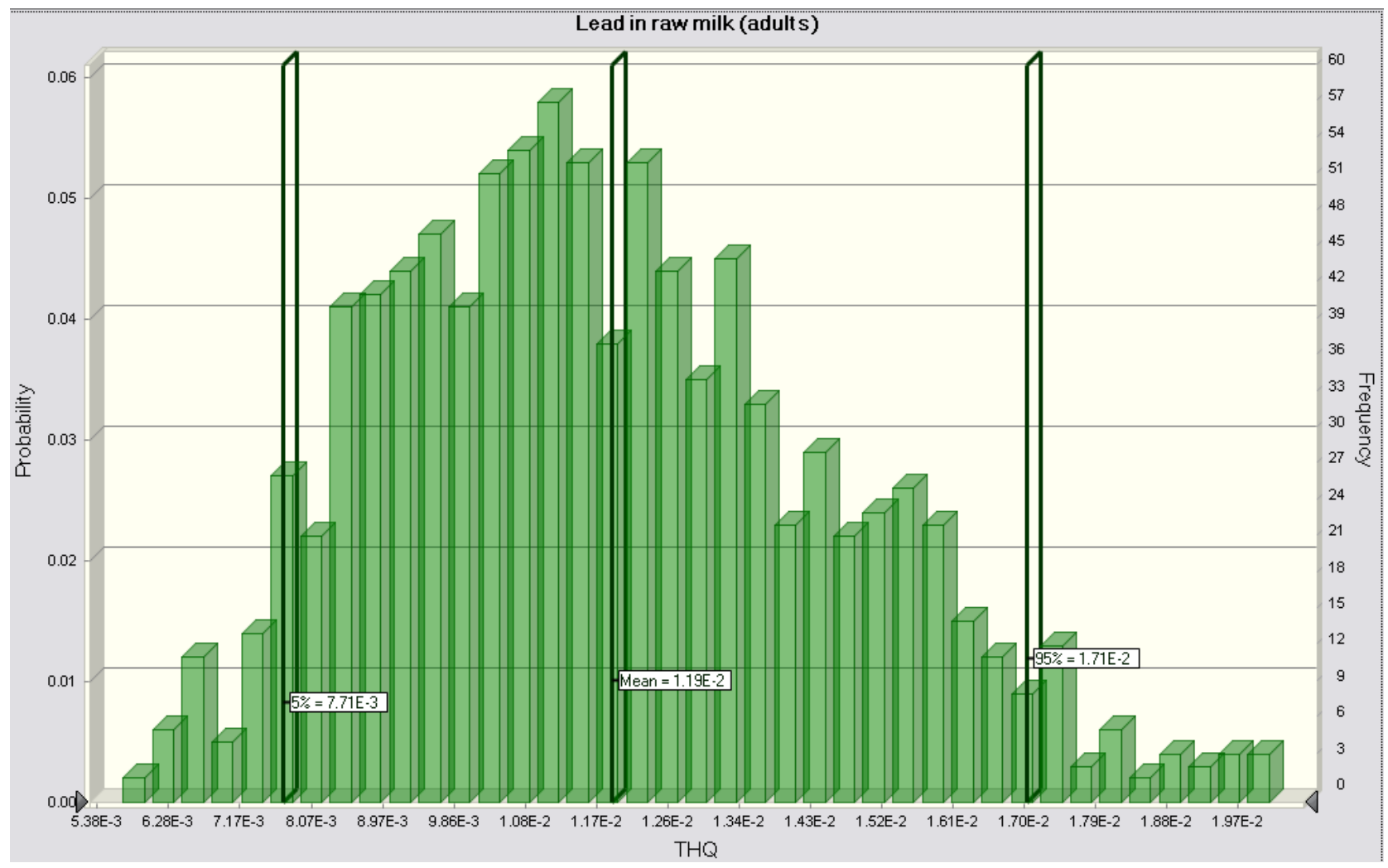


Masoumeh Madani-Tonekaboni, et al: Risk assessment of Cadmium and lead of milk in East Iran
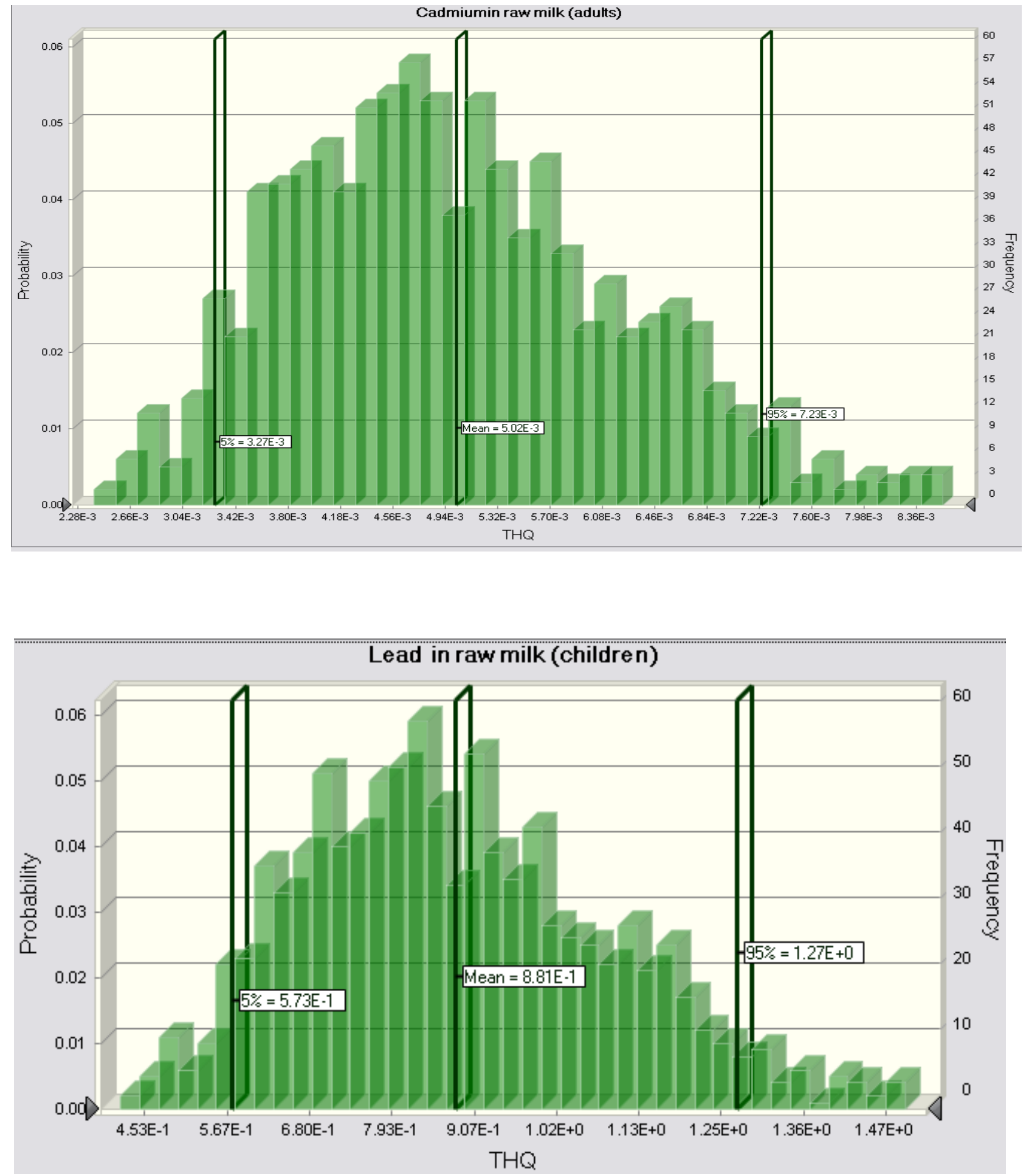
Masoumeh Madani-Tonekaboni, et al: Risk assessment of Cadmium and lead of milk in East Iran
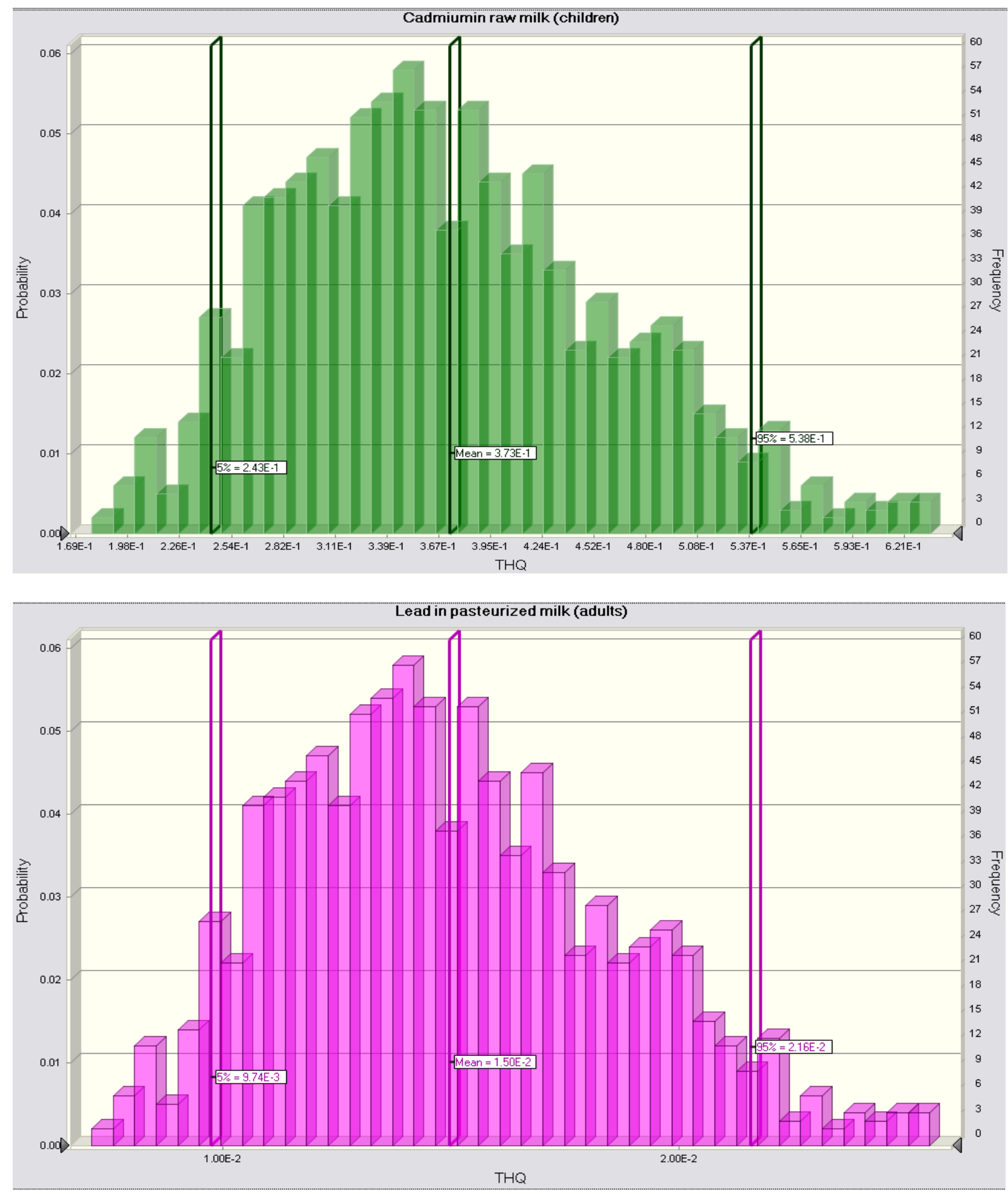
Masoumeh Madani-Tonekaboni, et al: Risk assessment of Cadmium and lead of milk in East Iran
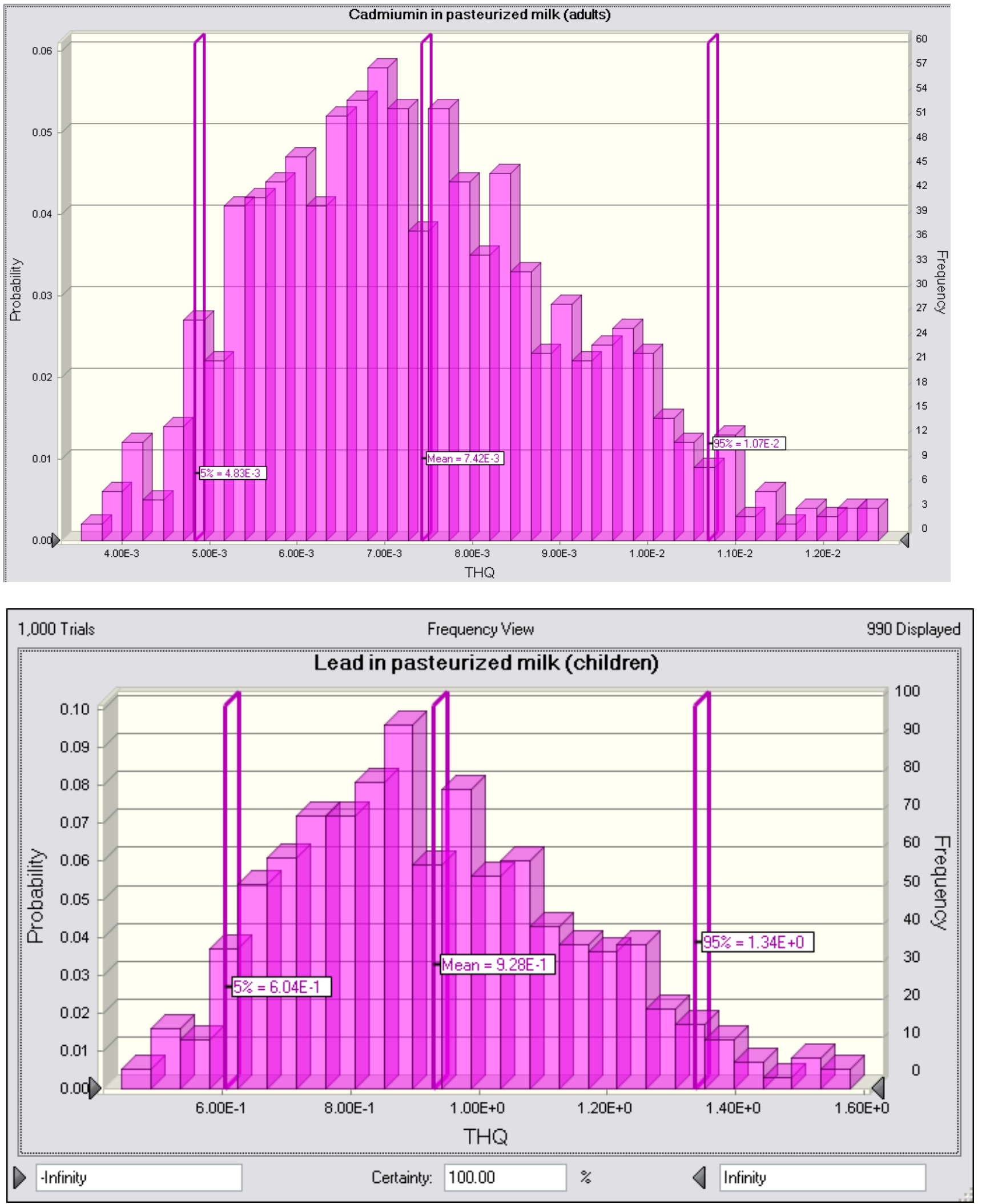


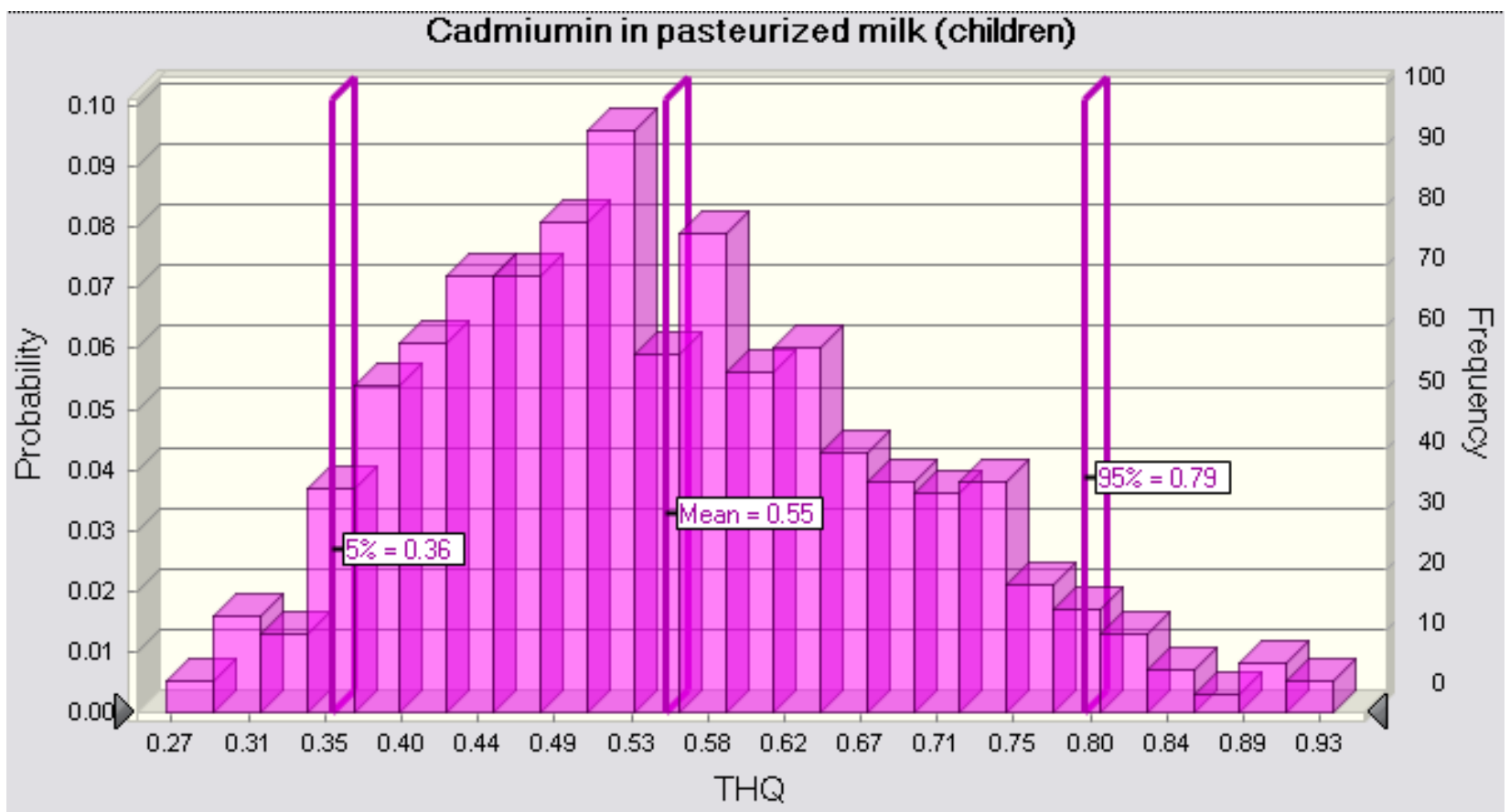

Figure 1. Simulation of THQ distribution for cadmium and lead through 10,000 iterations

\section{Conclusion}

Contaminant monitoring helps to improve safety and quality of foods and to assess potential risks by providing information on food contamination in societies. In this study, heavy metals including lead and cadmium were assessed in milks produced in various regions of Eastern Iran. Regarding milk quality data acquired from the exposure assessment, the THQ value was simulated for lead and cadmium. Findings showed that the THQ value was below 1 for all the samples. Therefore, all the male and female age groups were not at health risks due to milk consumption. However, products with greater consumption volumes should receive further attention. Continuous monitoring plays an important role in protecting consumer health against food contaminations.

\section{Acknowledgement}

This article is resulted from a research study (No. 9233) approved and financially supported by Shahroud University of Medical Sciences, Shahroud, Iran.

\section{Financial disclosure}

The authors declared no financial interest.

\section{Funding/Support}

This work was financially supported by the Shahroud University of Medical Sciences, Shahroud, Iran. (grant no. 9233).

\section{References}

1. Ataro A, McCrindle RI, Botha B, McCrindle CME, Ndibewu P. Quantification of trace elements in raw cow's milk by inductively coupled plasma mass spectrometry (ICP-MS). Food chemistry. 2008;111(1):243-8.

2. Maas S, Lucot E, Gimbert F, Crini N, Badot P-M .Trace metals in raw cows' milk and assessment of transfer to Comté cheese. Food chemistry. 2011;129(1):7-12.

3. Rafiei Nazari R, Noorian S, Arabameri M. Migration modelling of phthalate from non-alcoholic beer bottles by adaptive neuro-fuzzy inference system. Journal of the science of food and agriculture. 2018;98(6):2113-20.

4. Tajkarimi M, Faghih MA, Poursoltani H, Nejad AS, Motallebi A, Mahdavi H. Lead residue levels in raw milk from different regions of Iran. Food control. 2008;19(5):495-8.

5. Bilandžić N, Sedak M, Čalopek B, Luburić ĐB, Kolanović BS, Varenina I, et al. Lead Concentrations in Raw Cow and Goat Milk Collected in Rural Areas of Croatia from 2010 to 2014. Bulletin of environmental contamination and toxicology. 2016;96(5):645-9. 
6. Wimalawansa SJ. The role of ions, heavy metals, fluoride, and agrochemicals: critical evaluation of potential aetiological factors of chronic kidney disease of multifactorial origin $(\mathrm{CKDmfo} / \mathrm{CKDu})$ and recommendations for its eradication. Environmental geochemistry and health. 2016;38(3):639-78.

7. El Sayed EM ,Hamed AM, Badran SM, Mostafa AA. A survey of selected essential and heavy metals in milk from different regions of Egypt using ICP-AES. Food Additives and Contaminants: Part B. 2011;4(4):294-8.

8. Hayes AW, Kruger CL. Hayes' principles and methods of toxicology: CRC Press; 2014.

9. Su C, Zhang J, Li Z, Zhao Q, Liu K, Sun Y, et al. Accumulation and Depletion of Cadmium in the Blood, Milk, Hair, Feces, and Urine of Cows During and After Treatment. Biological trace element research. 2016:1-7.

10. Najarnezhad V, Akbarabadi M. Heavy metals in raw cow and ewe milk from north-east Iran. Food Additives \& Contaminants: Part B. 2013;6(3):158-62.

11. Caggiano R, Sabia S, D'Emilio M, Macchiato M, Anastasio A, Ragosta M, et al. Metal levels in fodder, milk, dairy products, and tissues sampled in ovine farms of Southern Italy. Environmental Research. 2005;99(1):48-57.

12. Kazi TG, Jalbani N, Baig JA, Kandhro GA, Afridi HI, Arain MB, et al. Assessment of toxic metals in raw and processed milk samples using electrothermal atomic absorption spectrophotometer. Food and Chemical Toxicology. 2009;47(9):2163-9.

13. Patra R, Swarup D, Kumar P, Nandi D, Naresh R, Ali S. Milk trace elements in lactating cows environmentally exposed to higher level of lead and cadmium around different industrial units. Science of the total environment. 2008;404(1):36-43.

14. Bilandžić N, Đokić M, Sedak M, Solomun B, Varenina I, Knežević Z, et al. Trace element levels in raw milk from northern and southern regions of Croatia. Food chemistry. 2011; 127(1): 63-66.

15. Najarnezhad V, Jalilzadeh-Amin G, Anassori E, Zeinali V. Lead and cadmium in raw buffalo, cow and ewe milk from west Azerbaijan, Iran. Food Additives \& Contaminants: Part B. 2015;8(2):123-7.

16. Anastasio A, Caggiano R, Macchiato M, Paolo C, Ragosta M, Paino S, et al. Heavy metal concentrations in dairy products from sheep milk collected in two regions of southern Italy. Acta Veterinaria Scandinavica. 2006;47(1): 1 .

17. Qin L-Q, Wang X-P, Li W, Tong X, Tong W-J. The minerals and heavy metals in cow's milk from China and Japan. Journal of health science. 2009;55(2):300-5.

18. Şanal H, Güler Z, Park YW. Profiles of non-essential trace elements in ewe and goat milk and their yoghurt, torba yoghurt and whey. Food Additives and Contaminants: Part B. 2011;4(4):275-81.
19. Licata P, Di Bella G, Potortì AG, Lo Turco V, Salvo A, Dugo Gm. Determination of trace elements in goat and ovine milk from Calabria (Italy) by ICP-AES. Food Additives and Contaminants: Part B. 2012;5(4):268-71.

20. Ogabiela E, Yebpella G, Adesina O, Udiba U, Ade-Ajayi F, Magomya A, et al. Assessment of Metals Levels in Cow Blood from Cow's Grazed around Zango, Zaria and Challawa Industrial Estate, Kano-Nigeria. Journal of Applied Environmental and Biological Sciences. 2011;1(4):69-73.

21. Sahayaraj PA, Ayyadurai K. Bioaccumulation of lead in milk of buffaloes from Cooum river belt in Chennai. 2009.

22. Bruhn J, Franke A. Lead and cadmium in California raw milk. Journal of dairy science. 1976;59(10):1711-7.

23. Antunovic Z, Bogut I, Sencic D, Katic M, Mijic P. Concentrations of selected toxic elements (cadmium, lead, mercury and arsenic) in ewe milk in dependence on lactation stage. Czech Journal of Animal Science. 2005;50(8):376.

24. Pavlović I, Sikirić M, Lukač-Havranek J, Plavljanić N, Brajenović N. Lead and cadmium levels in raw cow's milk from an industrialised Croatian region determined by electrothermal atomic absorption spectrometry. Czech journal of animal science. 2004;49(4):164-8.

25. Ismail A, Riaz M, Akhtar S, Ismail T, Ahmad Z, Hashmi MS. Estimated daily intake and health risk of heavy metals by consumption of milk. Food Additives \& Contaminants: Part B. 2015;8(4):260-5.

26. Tripathi M, Munot HP, Shouche Y, Meyer JM, Goel R. Isolation and functional characterization of siderophoreproducing lead-and cadmium-resistant Pseudomonas putida KNP9. Current microbiology. 2005;50(5):233-7.

27. Djahed B, Taghavi M, Farzadkia M, Norzaee S, Miri M. Stochastic exposure and health risk assessment of rice contamination to the heavy metals in the market of Iranshahr, Iran. Food and chemical toxicology. 2018;115:405-12.

28. Ghassemi H, Harrison G, Mohammad K. An accelerated nutrition transition in Iran. Public health nutrition. 2002;5(1a):149-55.

29. Abdollahi M, Mohammadi-Nasrabadi F, Houshiarrad A, Ghaffarpur M, Ghodsi D, Kalantari N. Socio-economic differences in dietary intakes: the comprehensive study on household food consumption patterns and nutritional status of IR Iran. Nutrition and Food Sciences Research. 2014;1(1):19-26

30. Guelinckx I, Ferreira-Pêgo C, Moreno LA, Kavouras, $\mathrm{SA}$, Gandy J, Martinez $\mathrm{H}$, et al. Intake of water and different beverages in adults across 13 countries. European journal of nutrition 2015a; 54, 45-55.

31. Guelinckx I, Iglesia I, Bottin J, De Miguel-Etayo P, Gonzalez-Gil E, Salas-Salvado J et al. Intake of water and beverages of children and adolescents in 13 
countries. European journal of nutrition. 2015b; 54, 6979.

32. Fakhri Y, Bjørklund G, Bandpei AM, Chirumbolo S, Keramati H, Pouya RH, et al. Concentrations of arsenic and lead in rice (Oryza sativa L.) in Iran: a systematic review and carcinogenic risk assessment. Food and chemical toxicology. 2018;113:267-77.

33. USEPA. (United States Environmental Protection Agency) Risk based screening table. Environmental Protection Agency, Cincinnati, OH (USA). Environmental ; 2015.

34. Khaneghah AM, Fakhri Y, Raeisi S, Armoon B, Sant'Ana AS. Prevalence and concentration of ochratoxin A, zearalenone, deoxynivalenol and total aflatoxin in cereal-based products: a systematic review and meta-analysis. Food and chemical toxicology. 2018;118:830-48.

35. ISIRI. Institute of Standards and Industrial Research of Iran. Food \& Feed- Maximum limit of heavy metals. ISIRI: Karaj; 2011.
36. Rahimi E. Lead and cadmium concentrations in goat, cow, sheep, and buffalo milks from different regions of Iran. Food chemistry. 2013;136(2):389-91.

37. Kim D-G, Kim M, Shin JY, Son S-W. Cadmium and lead in animal tissue (muscle, liver and kidney), cow milk and dairy products in Korea. Food Additives \& Contaminants: Part B. 2016;9(1):33-7.

38. Organization WH. Understanding the Codex Alimentarius: Food \& Agriculture Org.; 2018.

39. Additives JFWECoF, Organization WH. Evaluation of certain food additives and contaminants: sixty-first report of the Joint FAO/WHO Expert Committee on Food Additives: World Health Organization; 2004.

40. Sobhanardakani S. Human Health Risk Assessment of $\mathrm{Cd}, \mathrm{Cu}, \mathrm{Pb}$ and $\mathrm{Zn}$ through Consumption of Raw and pasteurized Cow's Milk. Iranian journal of public health. 2018;47(8):1172.

41. Meshref AM, Moselhy WA, Hassan NE-HY. Heavy metals and trace elements levels in milk and milk products. Journal of food measurement and characterization. 2014;8(4):381-8. 